\title{
PEMBELAJARAN COOPERATIVE SCRIPT DAN SENAM MATA DAPAT MENINGKATKAN KEMAMPUAN MEMBACA SISWA KELAS 8C SMPN 1 TIRTOYUDO TAHUN 2013/2014
}

\author{
Demes N. Dewi
}

\begin{abstract}
Penelitian bertujuan memperoleh waktu baca yang optimal, persentase pemahaman isi bacaan meningkat, peolehan KPM (kata per menit) di atas 200, dengan menggunakan teknik Cooperative Script dan Senam Mata dalam membaca. Metode yang dipakai deskriptif kuantitatif berupa PTK (penelitian tindakan kelas) dengan enam pertemuan. Alat pengumpul data berupa lembar observasi, tes dan kuis. Hasil analisis saat proses dan hasil membaca, dari 38 siswa diketahui (a) Ketercapaian waktu baca tertinggi 2 menit 7 detik, terus menurun menjadi 2 menit 0 detik, (b) Prosesentase pemahaman isi bacaan dari 50\% menjadi 55\% dan terus meningkat hingga $80 \%$, (c) Perolehan KPM pada pertemuan pertama hingga keempat, meningkat walaupun belum mencapai 200 , perolehan KPM di atas 200 baru tampak pada pertemuan kelima dan keenam. Dari data membaca dapat disimpulkan bahwa perolehan KPM (kata per menit) terus meningkat. Hasil pengamatan Senam Mata pada pertemuan pertama sampai ketiga tujuan Senam Mata belum tercapai, menginjak pertemuan keempat sampai keenam sambil dipandu guru dan diberi tugas Senam Mata di rumah baru tampak hasilnya , keberhasilan Senam Mata tampak pada pertemuan keempat, kelima, keenam terbukti dari 38 siswa (100\%) menyatakan tidak lelah mata dan tidak pusing. Dapat disimpulkan bahwa teknik Cooperative Script dan Senam Mata dapat meningkatkan kemampuan membaca, serta perolehan KPM (kata per menit) bisa mencapai di atas 200 hingga tertinggi 222.
\end{abstract}

Kata kunci : Cooperative Script, Senam Mata, KPM (kata per menit).

\section{PENDAHULUAN}

Upaya memacu perolehan KPM (kata per menit) dalam membaca kurang maksimal, belum mencapai 200. Satu penyebab utama adalah teknik pembelajaran. Untuk menggunakan teknik yang tepat peneliti melakukan studi awal, sabtu 7 Juni 2014 jam pertama pada 38 siswa kelas VIIIC. Data dianalisis tercatat perolehan waktu baca rata - rata 2 menit 4 detik, persentase pemahaman isi bacaan di bawah 50\% sebanyak 20 anak (53\%), di atas $50 \%$ baru dicapai 18 anak (47\%), KPM 101 hingga 140, sebanyak 31 anak $(81 \%)$, KPM tertinggi 151 sebanyak 7 anak (19\%). KPM (kata per menit) belum mencapai standar. Standar KPM untuk siswa SMP kelas VIII adalah 200 (Nurhadi B. Indonesia Kelas VIII : 26)

Saat proses membaca, 38 anak (100\%) menyatakan lelah mata dan pusing, untuk mengatasi lelah mata dan pusing dipakai teknik Senam Mata. Berdasar pengalaman peneliti setelah akhir membaca peneliti merasa lelah kadang pusing. Sebelum Senam Mata diterapkan ke siswa peneliti berlatih hingga 2 bulan, ikut seminar sebagai pendukung pengalaman peneliti, diterapkan juga pada teman sejahwat guru 2 sampai 6 orang, kepada anak dan keluarga. Dalam proses dan hasil membaca dipakai teknik Cooperative Script. Teknik Cooperative Script mempunyai karakteristik kerja sama, saling menunjang, menyenangkan, tidak membosankan, siswa aktif, terjadi umpan balik (Nurhadi dan Senduk : 2003). Senam Mata adalah teknik yang digunakan agar bola mata terbiasa lentur dan bergerak sesuai jangkauan mata, semakin lebar daya jangkau mata semakin efektif cara membaca.

Gerakan-gerakan bola mata beserta instruksinya adalah (1). Tutuplah mata, 
lalu gerakkan bola mata ke atas $6 x$ ke bawah 6x, kemudian buka mata, dan lihat ke atas 6x, dan ke bawah 6x. ketika menggerakkan mata ke atas tariklah nafas, ketika melihat ke bawah hembuskan nafas. Enam kali merupakan satu tahap, anda harus mempraktekkan masing - masing 6 tahap (total 36x). (2). Tutuplah mata, lalu gerakkan bola mata dari kiri ke kanan 6x, dari kanan ke kiri 6x,lalu buka mata, dan gerakkan mata kiri, ke kanan 6x, dan dari kanan ke kiri 6x. Enam kali merukan satu tahap, anda harus mempraktekkan masing - masing 6 tahap (total 36x). (3). Tutuplah mata, lalu gerakkan bola mata dari sudut kiri atas, ke sudut kanan bawah, kemudian kembali, dari sudut kanan bawah, ke sudut kiri atas, sebanyak 6x,lalu buka mata anda dan ulangi gerakan itu sebanyak 6x. Tariklah nafas ketika menggerakkan mata dari kiri atas ke kanan bawah dan hembuskan nafas ketika menggerakkan ke arah sebaliknya. Lakukan gerakan ini sebanyak 6 tahap (total 36x). (4). Tutuplah mata, lalu gerakkan bola mata dari sudut kanan atas ke sudut kiri bawah, kemudian sebaliknya, sebanyak 6x, lalu buka mata anda, ulangi gerakan itu sebanyak 6x. Tariklah nafas ketika menggerakkan mata dari sudut kanan atas ke sudut kiri bawah dan hembuskan nafas ketika menggerakkan ke arah sebaliknya. Lakukan gerakan ini sebanyak 6 tahap (total 36x). (5). Tutuplah mata, lalu gerakkan bola mata melingkar searah jarum jam, mulai dari sisi kiri $6 x$, lalu buka mata anda dan ulangi gerakan itu sebanyak 6x. Tariklah nafas, ketika mata bergerak ke atas dari sisi kiri dan hembuskan saat mata bergerak ke bawah sisi kanan. Lakukan gerakan ini sebanyak 4 tahap. (6). Tutuplah mata lalu gerakkan bola mata melingkar berlawanan arah jarum jam mulai dari sisi kiri 6x, lalu buka mata anda dan ulangi gerakan itu sebanyak 6x, tariklah nafas ketika mata bergerak ke atas dari sisi kiri dan hembuskan saat mata bergerak ke bawah sisi kanan. Lakukan gerakan ini sebanyak 4 tahap. (7). Pilihlah suatu objek yang jauh seperti puncak gunung, sebatang pohon, lalu tataplah objek itu, pada waktu yang bersamaan, anda harus bernafas dengan normal, kemudian hitunglah dalam hati " $1,2,3, \ldots$ dst". (8). Pilihlah suatu objek yang jauh dan tataplah objek itu, tutuplah mata, buka, tutup lagi. dan buka lagi. Tariklah nafas ketika anda membuka dan menutup mata (merupakan satu bagian). Praktekkan sebanyak 16 tahap. (Hariadi, Sehat Harmoni Indonesia. Malang: 2014).

KPM (kata per menit) adalah kecepatan membaca yang diperoleh dengan cara jumlah kata dalam teks dibagi dengan waktu ( dalam menit ) dikalikan persentase pemahaman yaitu skor yang didapat dibagi dengan skor tertinggi kali $100 \%$. (Nurhadi, B. Indonesia kelas VIII : 26).

Membaca adalah keterampilan menggerakkan otot-otot mata, bertujuan memahami isi bacaan. Mata dilatih untuk menemukan subyek kalimat (apa,siapa), predikat (melakukan apa) dan objek(pokok pembicaraan). (Downing dan Leong. 2002. Pengajaran Membaca).

\section{Tujuan penelitian}

(1) Meningkatkan kecepatan efektif membaca siswa SMP Kelas 8C SMPN 1 Tirtoyudo selama enam pertemuan dengan cara menghilangkan 8 kebiasaan buruk saat membaca, (2) Meningkatkan Persentase keterampilan berbahasa terutama kemampuan memahami isi 
bacaan siswa 8C SMP Negeri 1 Tirtoyudo melalui metode Cooperative Script

(3) Meningkatkan jumlah KPM siswa 8C SMP Negeri 1 Tirtoyudo Selama pertemuan 1 hingga keenam melalui penggabungan metode Senam Mata dan Copperative Script (4) Menghilangkan rasa pusing dan lelah mata pada saat KBM siswa SMP Negeri 1 Tirtoyudo.

\section{METODE}

Jenis penelitian yang dilakukan adalah penelitian tindakan kelas (PTK). Tempat penelitian dilaksanakan di SMP Negeri 1 Tirtoyudo. Kelas yang akan diteliti adalah kelas $8 \mathrm{C}$ dengan jumlah siswa sebanyak 38 anak yang terdiri dari 12 putri dan 16 putra. Waktu penelitian selama 6 kali pertemuan, yakni kegiatan prasiklus pada hari Jum'at dan Sabtu, 13 Juni 2014 dan 14 Juni 2014 dengan waktu tatap muka $2 \times 45$ menit. Pelaksanaan siklus I pada hari Jum'at dan Sabtu, 20 Juni 2014 dan 21 Juni 2014 dengan waktu tatap muka $2 \times 45$ menit dan pelaksanaan siklus II pada hari Jum'at dan Sabtu, 27 Juni 2014 dan 28 Juni 2014 dengan waktu tatap muka 2x45 menit.

Model penelitian yang digunakan adalah deskriptif kuantitatif (Sukmadinata : 2009), yaitu bentuk penelitian untuk mendeskripsikan proses dan hasil membaca dan Senam Mata. Kuantitatif berupa ketercapaian waktu baca, ketercapaian pemahaman isi bacaan, KPM hasil membaca, skor kuis Senam Mata.

\section{PROSEDUR PENELITIAN}

Mengikuti Kemmis dan MC. Taggart (dalam Arikunto, 2010: 15). Melalui tahap perencanaan, pelaksanaan, observasi/pengamatan, refleksi, yang dilakukan sebagai rangkaian kegiatan tiap pertemuan.

\section{Perencanaan}

Meliputi: penyusunan RPP, menyiapkan 6 (enam) tema dan jumlah kata yang berbeda, wacana pertama 550 kata, wacana kedua 600 kata, wacana ketiga 650 kata, wacana keempat 700 kata, wacana kelima 725 kata dan wacana keenam 750 kata. Menyiapkan 20 soal untuk masingmasing bacaan, menyiapkan jam dinding/ jam tangan untuk menghitung waktu baca, 2 (dua) lembar panduan Senam Mata, lembar observasi membaca dan observasi Senam Mata tiap pertemuan, pemberian penilaian skor pemahaman. Tiap jawaban benar diberi skor 5, nilai maksimal $20 \times 5$ $=100$, menyiapkan penghitungan KPM (kata per menit).

\section{Pelaksanaan membaca}

Membaca teks bacaan 9,11,16, 14,15,13 dengan teknik Cooperative Script dengan langkah - langkah sebagai berikut : (1) Salam, doa, persensi, pre tes membaca (2) Menyampaikan tujuan membaca (3) Sebelum kegiatan membaca dimulai persiapkanlah dari rumah jam tangan, untuk menghitung waktu baca. (4) Guru menyuruh siswa berhadapan dengan teman sebangku, untuk menentukan kesepakatan pemeran dan kesepakatan waktu mulai membaca. (5) Pemeran pertama, berlaku sebagai pencatat waktu dimulainya dan berakhirnya proses membaca, bergantian peran sebalikanya. (6) Perhatikan dengan cermat arah jarum jam ( tandailah!) saat mulai membaca dan berakhirnya proses membaca. (7) Catat waktu mulai membaca dan catat pula waktu berakhirnya ( jumlah menit dan detik), laporkan ke guru. (8) Temukan gerakan-gerakan yang dilakukan teman saat membaca sebagai gerakan 
yang dipandang sebagai penghambat proses membaca. Catatlah di buku pekerjaan kalian, laporkan ke guru. (9) Selesai membaca ada pertanyaan untuk memahami isi bacaan. (10) Pertanyaan dibaca guru siswa menjawab sesuai pilihan benar atau salah (11) Selesai manjawab, koreksi bersama untuk mengetahui skor pemahaman bacaan. (12) Laporkan skor yang dicapai ke guru. Guru bersama siswa menghitung persentase dan KPM, hasil KPM akhir ditulis di buku nilai guru dan di buku catatan siswa. (13) Guru berkeliling, mengevaluasi gerakan, mencatat gerakan yang dianggap menggangu atau menghambat proses membaca. (14) Guru bersama siswa membuat kesimpulan.

Pelaksanaan Cooperative Script dalam Senam Mata langkah - langkahnya sebagai berikut: (1) Salam, doa, persensi, pre tes Senam Mata, menyampaikan tujuan senam mata. (2) Membagikan dua lembar gambar Senam Mata untuk dibaca dan dipahami kemudian mendemonstrasikannya. (3) Guru menyuruh siswa untuk berhadapan dengan teman sebangku.(4) Siswa menetapkan kesepakatan sebagai pemeran pertama dan sebagai pengamat dengan teman sebangkunya. (5) Siswa yang satunya sebagai pengamat, si pengamat mencatat nomor gerakan yang kurang sesuai. Untuk langkah pembenaran gerakan. Melaporkan ke guru perubahan yang dirasakan siswa. (6) Siswa bertukar peran, semula sebagai pemeran, bertukar menjadi pengamat dan sebaliknya. (sambil tetap mencatat gerakan yang kurang sesuai). (7) Guru memberi instruksi untuk mulai gerakan pertama pada gambar 1 sesuai perintah di bawah gambar. Guru memberi aba-aba untuk melakukan gerakan kedua. Selesai gerakan kedua, berlanjut kegerakan ketiga sampai kedelapan. (8) Guru berkeliling, mengevaluasi gerakan, mencatat gerakan yang kurang sesuai, untuk langkah pembenahan kekeliruan gerakan berikutnya. (9) Guru memandu gerakan, memantau, mengevaluasi saat proses dan membetulkan gerakan Senam Mata dengan sempurna. Siswa mengamati gerakan yang dicontohkan guru. Kemudian mendemonstrasikan. (10) Siswa bersama guru melakukan gerakan Senam Mata dengan benar. Guru memberi tugas Senam Mata untuk dilakukan di rumah. Siswa melaporkan keluhan atau perubahan yang terjadi pada pertemuan berikutnya. (11) Bertanya jawab berupa kuis hasil senam mata.

\section{Observasi}

Observasi merupakan kegiatan observer/peneliti melakukan pencatatan terhadap objek saat proses dan hasil membaca dan Senam Mata tiap pertemuan. Pengamatan terhadap proses membaca diketahui ada 8 kesalahan yaitu (1) Menyuarakan kata-kata yang sedang dibaca. Membaca merupakan proses berpikir, dan berpikir itu lebih cepat dari berbicara. Oleh karena itu, bila pada waktu membaca (berarti sedang berpikir), mengeluarkan suara dengan menggerakkan bibir, maka kecepatan membacanya akan terhambat. (2) Membaca kata demi kata. (3) Membaca dengan menggunakan alat penunjuk seperti pensil, telunjuk dan lainlain. (4) Menggerakkan kaki atau anggota tubuh lain. (5) Konsentrasi terpecah. (6) Bergumam atau bersenandung. (7) Berhenti lama pada awal kalimat, paragraf. (8) Melakukan regresi (mengulang) bagian yang dibaca. 
Kedelapan kesalahan ini tercatat pada pengamatan pertemuan pertama kedua dan ketiga. Berdasar pengamatan proses membaca setelah direvisi, pada pertemuan keempat, kelima dan keenam, terjadi perubahan (1) Diam dan fokus (2) Membaca berupa kalimat/paragraf Membaca tanpa alat bantu telunjuk atau alat bantu lain (4) Tidak menggerakkan kaki atau anggota tubuh lainnya (5) Tidak bergumam (6) Cepat beralih ke kalimat / paragraf selanjutnya (7) Konsentrasi terpusat (8) tidak mengulang atau regresi.

\section{Refleksi}

Melalui Obervasi terhadap proses Senam Mata, pada saat berlangsungnya Senam Mata guru memantau sebagai berikut: (1) Pada gerakan pertama siswa belum menutup mata dan belum menarik nafas, belum menghembuskan nafas dengan benar. Hal ini menyebabkan rasa pusing, apalagi jika perut dalam keadaan kosong. (2) Pada gerakan kedua, siswa juga belum menutup mata dan belum manarik nafas, belum menghembuskan nafas dengan benar. (3) Pada gerakan ketiga, kali ini sudah menutup mata tetapi pengaturan nafasnya belum benar, perlu dibenahi dan dilakukan secara disiplin. (4) Pada gerakan keempat, perlu pengaturan nafas yang benar, tetapi siswa belum melakukannya dan belum menutup mata pula. (5) Pada gerakan kelima, gerakan bola mata melingkar searah jarum jam, terjadi kesalahan gerakan, kepala siswa ikut digerakkan, semakin memperparah rasa pusing. Berkosentrasilah dengan tepat agar rasa pusing segera hilang! (6).Begitu pula pada gerakan keenam, bola mata digerakkan berlawanan arah dengan jarum jam, sulit dilakukan, sebab kepala ikut digerakkan. (7) Gerakan ketujuh sudah benar. (8) Gerakan kedelapan lebih mudah dikerjakan karena siswa sudah terbiasa, pengaturan nafas sudah sempurna. Begitu pula saat membuka dan menutup mata pun sudah tepat. Guru memandu ulang gerakan pertama, kedua, ketiga, keempat, kelima, ketujuh dan kedelapan. Siswa mendemonstrasikannya dengan sungguhsungguh pada pertemuan selanjutnya. Observasi pelaksanaan Senam Mata pertemuan pertama untuk acuan pertemuan selanjutnya.

\section{Alat pengumpul data}

Alat Pengumpul data berupa catatan dan pengamatan proses membaca, pengamatan proses Senam Mata, tes akhir bacaan, kuis Senam Mata pertemuan pertama sampai pertemuan keenam. Dilanjutkan menganalisis, mengatur, merekapitulasi, mengumpulkan secara sistematis transkrip dan proses hasil membaca dan Senam Mata untuk mengetahui perolehan waktu baca, merekapitulasi hasil tes dengan menghitung skor yang tercapai beserta persentase pemahaman isi bacaan, menghitung KPM.

\section{HASIL DAN PEMBAHASAN}

Subjek penelitian ini adalah siswa kelas 8C SMP Negeri 1 Tirtoyudo tahun Pelajaran 2013/2014, yang berjumlah 38 siswa. Kemampuan membaca siswa melalui model pembelajaran Cooperative Sript dan Teknik Senam Mata, mengalami peningkatan pada Siklus I dan Siklus II tampak pada Tabel 1 berikut ini: 
Tabel 1. Hasil Tes Pemahaman Isi bacaan Prasiklus, Siklus I dan Siklus II

\begin{tabular}{|c|l|c|c|c|c|c|c|}
\hline \multirow{2}{*}{ No } & \multicolumn{2}{|c|}{ Kategori Penilaian } & \multicolumn{2}{|c|}{ PraSiklus } & \multicolumn{2}{c|}{ Siklus I } & \multicolumn{2}{c|}{ Siklus II } \\
\cline { 3 - 8 } & & 1 & 2 & 3 & 4 & 5 & 6 \\
\hline 1 & $\begin{array}{l}\text { Perolehan waktu baca } \\
\text { (..menit,...detik) }\end{array}$ & 2,50 & 2,30 & 2,20 & 2,00 & 1,70 & 1,50 \\
\hline 2 & Persentase Pemahaman & $56 \%$ & $57 \%$ & $72 \%$ & $76 \%$ & $80 \%$ & $85 \%$ \\
\hline 3 & Jumlah KPM & 141 & 150 & 168 & 182 & 211 & 220 \\
\hline
\end{tabular}

Berdasarkan tabel di atas nilai ratarata prasiklus adalah $56,5 \%$, termasuk dalam kategori cukup. Pada Siklus I pemahaman isi bacaan diperoleh rerata skor $74 \%$, hal ini tergolong cukup dan pada Siklus II pemahaman isi bacaan diperoleh rerata skor $83 \%$ hal ini tergolong baik. Hal ini membuktikan pembelajaran dari prasiklus ke siklus I meningkat sebanyak $17,5 \%$, dan dari siklus I sampai ke siklus II meningkat sebanyak $9 \%$ atau dengan kata lain berhasil.

Tabel 2. Hasil perolehan kuis Senam Mata dari 38 siswa

\begin{tabular}{|c|c|}
\hline $\begin{array}{l}\text { 1. Pertemuan } 1 \\
38 \text { siswa menjawab pusing. } \\
38 \text { siswa menjawab lelah mata. }\end{array}$ & $\begin{array}{l}\text { 2. Pertemuan } 2 \\
8 \text { siswa menjawab pusing, } 30 \text { menjawab tidak } \\
\text { pusing } \\
8 \text { siswa menjawab lelah mata, } 30 \text { menjawab tidak } \\
\text { lelah mata }\end{array}$ \\
\hline $\begin{array}{l}\text { 3. Pertemuan } 3 \\
3 \text { siswa menjawab pusing, } 35 \text { menjawab tidak } \\
\text { pusing } \\
3 \text { siswa menjawab lelah mata, } 35 \text { menjawab } \\
\text { tidak lelah mata }\end{array}$ & $\begin{array}{l}\text { 4. Pertemuan } 4 \\
38 \text { siswa menjawab tidak pusing } \\
38 \text { siswa menjawab tidak lelah mata }\end{array}$ \\
\hline $\begin{array}{l}\text { 5. Pertemuan } 5 \\
38 \text { siswa menjawab tidak pusing } \\
38 \text { siswa menjawab tidak lelah mata }\end{array}$ & $\begin{array}{l}\text { 6. Pertemuan } 6 \\
38 \text { siswa menjawab tidak pusing } \\
38 \text { siswa menjawab tidak lelah mata }\end{array}$ \\
\hline
\end{tabular}

Berdasarkan tabel diatas pada pertemuan pertama, 38 siswa menjawab pusing dan lelah mata. Berarti Senam Mata belum berhasil, menginjak pertemuan kedua sambil dipandu guru dan diberi tugas di rumah, baru terlaksana. Tampak hasilnya pada tabel 2 , rasa pusing dan lelah mata sudah berkurang. Senam Mata benar - benar dirasakan hasilnya setelah pertemuan ketiga, keempat, kelima serta keenam, tercatat sebanyak 38 siswa menjawab tidak lelah mata dan tidak pusing. Asal rutin dan disiplin dilaksanakan 3 kali sehari, satu kali menjelang tidur, satu kali sesudah bangun tidur dan satu kali sebelum KBM dimulai atau kegiatan lainnya.

\section{KESIMPULAN}

Peningkatan kemampuan memahami isi bacaan siswa SMP Negeri 1 Tirtoyudo tahun pelajaran 2013/2014 setelah dilakukan penelitian tindakan kelas menggunakan model pembelajaran Cooperative Script dan teknik Senam Mata diketahui dari rata - rata pada siklus I mencapai $74 \%$ yang termasuk dalam kategori baik. Setelah pemahaman isi 
bacaan melalui metode Coopertative Script dan Senam Mata pada Siklus II, diperoleh rata - rata $83 \%$ dan termasuk dalam kategori sangat baik . Penggabungan teknik Cooperative Script dan Senam Mata dapat meningkatkan persentase pemahaman isi bacaan serta dapat meningkatkan kecepatan membaca siswa kelas 8C SMPN 1 Tirtouyudo. Jumlah KPM (kata per menit) yang diperoleh siswa bisa meningkat dengan catatan, siswa tidak melakukan 8 (delapan) kesalahan pada waktu pelaksanaan membaca. Penerapan teknik pertama hingga kedelapan pada Senam Mata dengan tepat, membuat siswa tidak pusing dan tidak lelah mata saat proses membaca.

\section{Saran}

Model Cooperative Script pada pembelajaran membaca sangat menunjang peningkatan perolehan KPM (kata per menit). Senam Mata sangat membantu siswa dan para pengajar khususnya guru mata pelajaran bahasa Indonesia dan guru mata pelajaran lain yang mempunyai keluhan lelah mata atau pusing saat proses berlangsungnya membaca dan berakhirnya membaca. Sangat dianjurkan, maka ikutilah gerakan 1 sampai 8 pada intruksi Senam Mata secara rutin dan disiplin. Hasil penelitian ini perlu pengembangan lebih lanjut, artinya perlu ada penelitian berkelanjutan agar perolehan KPM (kata per menit) optimal pada ketrampilan membaca jenis lain. Hasil penelitian ini hendaknya disosialisasikan kepada sekolah menengah pertama terutama di kabupaten Malang dan sekitarnya serta di luar kabupaten Malang dan bermanfaat secara umum bagi Pengelola Pendidikan Tingkat Kabupaten, Provinsi dan Pusat.

\section{DAFTAR RUJUKAN}

Alwi , Hasan dkk. 2007. Kamus Besar Bahasa Indonesia. Jakarta: Gramedia Pustaka Utama

Arikunto, Suharsini. 1988. Prosedur Penelitian Suatu Pendekatan Praktek. Jakarta: Rineka Cipta.

Hariadi. 2014. Mata Bersinar Dengan Senam Mata, Sehat Harmoni Indonesia. Malang: Gramedia.

Huda, Miftahul. 2011. Cooperative Learning Metode, Teknik, Struktur, dan Model Penerapan. Yogyakarta: Pustaka Pelajar.

Lie, Anita. 2008. Cooperative Learning, Jakarta: Gramedia.

Rosda Karya, Muhammad. 2011. Metode Penelitian Bahasa. Yogyakarta: ArRuzz Media.

Rusman. 2011. Model-model pembelajaran mengembangkan profesionalisme guru. Jakarta: Rajawali Pers.

Suprijono, Agus. 2009. Cooperative Learning. Yogyakarta: Pustaka Pelajar. 